Annals of Warsaw University of Life Sciences - SGGW

Land Reclamation No 49 (3), 2017: 167-177

(Ann. Warsaw Univ. of Life Sci. - SGGW, Land Reclam. 49 (3), 2017)

\title{
Modeling of water flow in multi-channel river system in the Narew National Park
}

\author{
PAWEE MARCINKOWSKI, ADAM KICZKO, TOMASZ OKRUSZKO \\ Faculty of Civil and Environmental Engineering, Warsaw University of Life Sciences - SGGW
}

\begin{abstract}
Modeling of water flow in multi-channel river system in the Narew National Park. Anastomosing rivers constitute a rare example of multi-channel systems, which used to be very common before the agricultural and industrial development. Presently few of them remain worldwide and the only example in Poland is the Upper River Narew within Narew National Park. Although hydraulic modeling using one-dimensional models is commonly used to describe water flow in rivers, for multi-channel rivers problem is more complicated. For this type of rivers it is expected that the feedback between process of plants growth (expressed by Manning's coefficient) and distribution of flow in anabranches is high. However, assignment procedure on roughness coefficients in splitting and rejoining channels is laborious and difficult. Therefore, for efficient water flow modeling in multi-channel systems a stand-alone hydraulic model equipped with automatic optimization procedure was developed. Optimization and validation stages, based on field measurements data of discharge and water levels, indicated that the model accurately simulates water flow in multi-channel system.
\end{abstract}

Key words: anastomosing river, steady-flow model, Manning's coefficient, optimization

\section{INTRODUCTION}

Multi-channel anastomosing rivers occur in a variety of topographical and climatic environments (Nanson and Croke 1992, Nanson and Knighton 1996). They were historically common before extensive agricultural and industrial development in river valleys (Walter and Merritts 2008, Lewin 2010, Marcinkowski et al. 2017). Presently, few of them persist and their protection is an international conservation priority. One of the last preserved examples of anastomosing type of river in Europe is in the Upper River Narew (north-eastern Poland). The unique river planform is formally protected as a Narew National Park (NNP) and Natura 2000 site (so-called Birds and Habitats Directives).

Hydraulic modeling using one-dimensional models is commonly used to describe water flow in rivers (Horritt and Bates 2002, Romanowicz et al. 2009, 2010, Mashriqui et al. 2014). Less popular, because of the limited number of research areas, is the use of models for multi-channel rivers. The specificity of such systems requires detailed recognition of flow distribution conditions between existing anabranches and accurate measurement of their geometry (Van et al. 2012). An important factor influencing the flow resistance in channels of the anastomosing river system is vegetation (Kiczko et al. 2011). River channel capacity depends on the density of aquatic vegetation - determining the distribution of flow. The degree of channel obstruction by plants strictly depends on the flow velocity (Riis and Biggs 2003). 
Therefore, in multi-channel systems it is expected that the feedback between process of plants growth and distribution of flow in anabranches is high.

One of the most crucial steps in water flow modeling is identification of model parameters. Whilst in single channel systems this procedure is relatively simple and can be done manually, in complex interconnected system of channels it becomes difficult and laborious. Additionally, due to closed-source character of the hydraulic models it is not possible to interfere in model code to build an automatic optimization procedure for existing models. Therefore, for efficient water flow modeling in multi-channel systems it was necessary to develop a stand-alone hydraulic model equipped with automatic optimization procedure.
Against this background, the objective of this study is to develop a one-dimensional steady flow model for the anastomosing section of the NNP supported by the automatic procedure for parameters optimization.

\section{MATERIAL AND METHODS}

\section{Site description}

The Upper River Narew is a lowland, low-gradient $(0.0002 \mathrm{~m} / \mathrm{m})$ river situated in north-eastern Poland (Fig. 1). Within the NNP, the river is characterized by a complex network of small interconnected, unconfined channels draining peat substrate. The river valley is occupied by wetlands with early growth

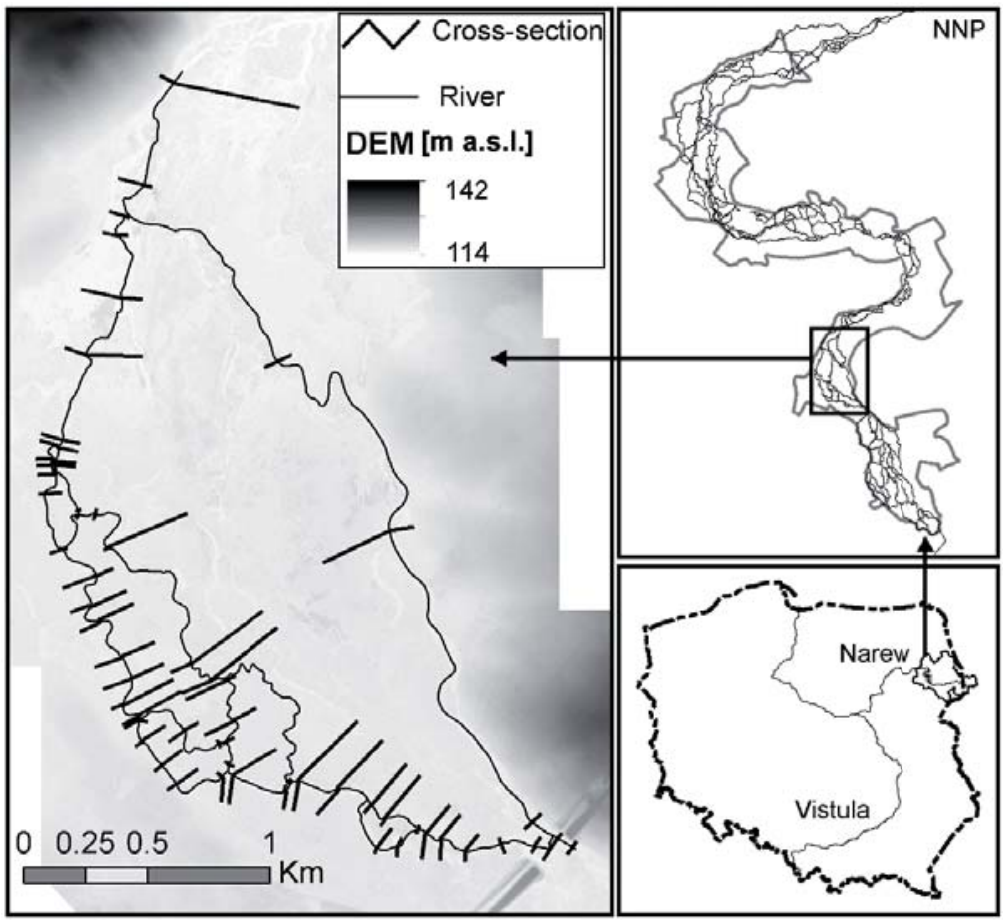

FIGURE 1. Study location 
sedge and reed communities. In recent decades uncontrolled expansion of common reed (Phragmites australis) became a serious problem causing significant loss of biodiversity (Próchnicki 2005) and the loss of anabranches (Marcinkowski et al. 2017). The abundance of aquatic vegetation in river channels depends on the water depth and current velocity. Active channels deeper than $2 \mathrm{~m}$ are free of vegetation but shallower stretches are promptly colonized by both, emergent and submerged macrophytes. The study focuses on a four-kilometer long stretch of the anastomosing section within the NNP.

\section{Fieldwork and modeling approach}

The specificity of such systems requires detailed recognition of flow distribution conditions between existing anabranches and accurate measurement of their geometry. Field measurements conducted for the purpose of this research included discharge measurements at all confluences and channel geometry and water level measurements using GPS (Fig. 1). To capture the impact of vegetation on water level and flow distribution measurements were conducted in two different periods: during high water levels in dormancy season; during low water levels in growing season. In both cases only river flows bellow bankfull stages were considered.

In this research in the first instance Hydrological Engineering Center - River analysis system (HEC-RAS model) was used as one of the most common tools for solving eco-hydraulic problems (Pappenberger et al. 2005, Cisowska and Hutchins 2016). Model HEC-RAS was developed by the US Corps of Engineers
(Brunner 1995) and for the Narew River its one-dimensional module was used.

In the first step HEC-GeoRAS module was used to build-up geometry network based on one-meter resolution digital elevation model (DEM) obtained from light detection and ranging (LiDAR) scanning. For each cross-section in-stream bed and bank elevations were automatically corrected and replaced by actual values from field GPS measurements. In the second step an enhanced geometry was interpolated with 50-meter spacing between measured cross-sections and exported to text file and imported to HEC-RAS version 4.1.0.

The one-dimensional module for a steady state flow allows to model the flow distribution in multi-channel system. It is done under the assumption that for subcritical flow the energy line at a junction where channels split should be equal. The flow distribution is obtained by minimizing the differences of the energy head at such splitting junctions with the respect to the discharge. However, preliminary results of HEC-RAS optimization algorithm for the flow distribution in the multi-channel system, appeared to be inconvenient, as both discharges and parameters describing the channel resistance, had to be identified. Because of HEC-RAS closed-source form the use of any automated parameter identification techniques is infeasible.

\section{Multi-channel flow routing model in MATLAB}

Difficulties in applying the automated procedure for parameters optimization in HEC-RAS for a complex anastomosing river system consisting of interconnected channels required elaborating a new 
tool. For this purpose a one-dimensional steady flow model was developed in the MATLAB computing environment, hereafter referred to as multi-channel flow routing model (MFRM). To capture the impact of vegetation on water levels and flow distribution MFRM was applied for two different hydrological and vegetation conditions: during growing season; during dormancy season. Computations were started from the most downstream cross-section with fixed (measured) water level and were processed progressively up-stream between cross-sections for each branch. At junctions, calculated water level from downstream branch was assigned to upstream branch/branches. For parallel rejoining branches mean water level was assigned to downstream branch.

For the purpose of this research following assumptions were made: steady flow conditions; one-dimensional flow is considered (only the velocity components in the flow direction are taken into account, and the elevation of the energy line is the same in the whole cross-section; river flow can be expressed in terms of energy conservation equation; discharge within each river branch is uniform; flow is subcritical.

\section{Equations}

Likewise in HEC-RAS, in newly designed MATLAB model, Bernoulli's energy conservation equation was used (Fig. 2), which for neighboring cross-sections can be expressed as follows:

$z_{1}+\frac{\alpha_{1} v_{1}^{2}}{2 \mathrm{~g}}=z_{2}+\frac{\alpha_{2} v_{2}^{2}}{2 \mathrm{~g}}+h_{\text {loss }}$

where:

$z_{1}, z_{2}$ - water level in cross-sections 1 and $2(\mathrm{~m})$;

$\alpha_{1}, \alpha_{2}-$ Coriolis coefficients in cross-sections 1 and 2;

$v_{1}, v_{2}$ - mean flow velocities in cross-sections 1 and $2(\mathrm{~m} / \mathrm{s})$;

$\mathrm{g}$ - acceleration of gravity $\left(\mathrm{m} / \mathrm{s}^{2}\right)$;

$h_{\text {loss }}$ - energy loss/hydraulic gradient.

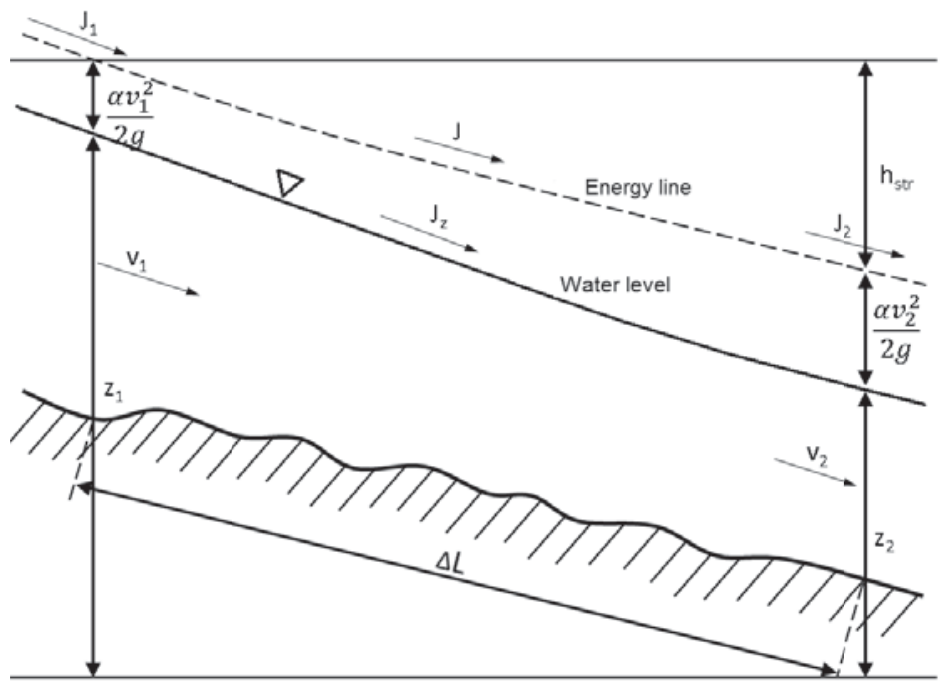

FIGURE 2. Description of Bernoulli's energy conservation equation components 
Energy losses of the stream $\left(h_{\text {loss }}\right)$ due to flow resistances between the two cross-sections are referred to as the hydraulic gradient $(J)$ :

$$
J=\frac{v^{2} n^{2}}{R^{\frac{4}{3}}}
$$

where:

$n$ - Manning's coefficient $\left(\mathrm{m}^{-1 / 3} \cdot \mathrm{s}\right)$,

$R$ - hydraulic radius (m).

Energy losses caused by friction are expressed by the Manning's equation:

$$
v=\frac{1}{n} R^{\frac{2}{3}} J^{\frac{1}{2}}
$$

After transformation of Equation (1) water level in upstream cross-section $\left(z_{1}\right)$ can be calculated as follows:

$$
z_{1}=z_{2}+\frac{\alpha_{2} v_{2}^{2}-\alpha_{1} v_{1}^{2}}{2 \mathrm{~g}}+\frac{J_{1}+J_{2}}{2} \Delta L
$$

Flow distribution among the river branches was modeled in a same manner as in the HEC-RAS. According to Equation (4), for the subcritical flow conditions the energy level at the cross-section immediately downstream the split of two or more channels depends only on the downstream water level and velocity. However, at the split the energy levels should be equal to preserve the subcritical flow profile. This additional condition allows determining the flow distribution among branches that ensures same energy levels at the split. In multi-channel flow routing model it was done by minimizing differences between energy levels in first cross-sections downstream the split. It has to be noted that it did not require determining discharge values for all branches. Using a balance equation that arises from the river network topology it was possible to set certain values of discharge as independent and remaining as dependent. In the result for 22 branches it was necessary to determine only 8 values of discharge in minimization task, for a given total discharge. Minimization was done using the MATLAB algorithm for the constrained optimization (fmincon function).

\section{Identification of the roughness coefficients}

One of the main difficulties in the presented study was the problem of identifying models' parameters, which were Manning's roughness coefficients. It was assumed that each channel can be characterized with a single value of the coefficient. Floodplain roughness was not considered, as only channel flows were investigated (bellow bankfull stages). Nevertheless, for the analyzed river reach, it was necessary to identify 22 values of roughness coefficients. The difficulty came with dependency of the flow distribution among channels on the roughness. In the direct form the parameter identification would require estimation of $22+12$ variables (22 roughness coefficients and 12 discharge values). Here however, the problem could be simplified, as the observations of water levels at junctions with measured flow distributions were available.

In the first step non-linear programming solver finding minimum of constrained non-linear multivariable function was applied to identify Manning's coefficient for all branches. At this stage, for all branches, measured discharge was 
implemented as a fixed value and water level at each junction was compared with the GPS measured value. As the result, a set of Manning's coefficients were estimated for which the minimum difference between computed and measured water level, under fixed flow conditions for each junction, was obtained.

However, at part of the junctions, identified roughness coefficients still gave different $( \pm 5 \mathrm{~cm})$ water levels at rejoining branches, and hence to eliminate these differences the flow distribution was recalculated to ensure agreement of energy levels at channel splits. At this stage, identified Manning's coefficients from the first stage were used. Afterwards, absolute differences between measured discharge and water levels and simulated ones at each junction were computed to assess the model accuracy.

To validate the model independent dataset of measured discharges and water levels was used. The validation procedure started from initiating the measured water level at the most downstream branch and optimization of flow under fixed Manning's coefficients. Afterwards, optimized discharge distribution and water levels were compared with the measured ones and the differences were calculated.

\section{RESULTS AND DISCUSSION}

In the first stage model was developed for high water levels $\left(Q=16 \mathrm{~m}^{3} / \mathrm{s}\right)$ for the dormancy season, when vegetation abundance in channels is very low. Roughness coefficients' optimization, based on fixed discharges, resulted in identification of a set of 22 Manning's coefficients, for all river branches, ranging from 0.027 to 0.054 ( 0.040 on average), which appears to be reasonable comparing with the literature (Arcement and Schneider 1989). In the second stage of optimization - based on fixed Manning's coefficients - discharge distribution was slightly adjusted and the differences in energy levels at parallel branches were eliminated (average difference equal to $1.7 \cdot 10^{-8} \mathrm{~m}$ ). Since the flow distribution between branches slightly changed (by $0.09 \mathrm{~m}^{3} / \mathrm{s}$ on average), absolute differences between measured and modeled water levels were recalculated and gave satisfactory results ranging from 0.1 to $5 \mathrm{~cm}$ ( $2 \mathrm{~cm}$ on average $)$ - Table 1 .

In the second stage input dataset, e.g. measured water levels and discharges, covering the low flow period $\left(Q=7.4 \mathrm{~m}^{3} / \mathrm{s}\right)$ during the growing season, was introduced to MFRM. To assess the significance of roughness coefficients in model performance, previously identified set of Manning's coefficients was kept in the first iteration. Results indicated that the average difference between measured and computed water levels differed on average by $30 \mathrm{~cm}$. It means that during the growing season, when the abundance of in-stream vegetation is high, roughness coefficients should be - as expected - much higher. After the first stage of optimization new set of Manning's coefficients was obtained, ranging from 0.027 to 0.089 ( 0.61 on average). Differences in measured and computed water levels at the junctions were slight ( $2 \mathrm{~cm}$ on average). The next step required optimization of discharge distribution (by $0.03 \mathrm{~m}^{3} / \mathrm{s}$ on average) at junctions. Recalculation of absolute differences between measured and computed water levels at the junctions based on 
TABLE 1. Differences in water level obtained during subsequent optimization procedures for high water period

\begin{tabular}{|c|c|c|}
\hline Junction number & $\begin{array}{c}\text { Difference in energy level } \\
\text { between parallel branches } \\
(\mathrm{m})\end{array}$ & $\begin{array}{c}\text { Difference between measured and } \\
\text { computed water level } \\
(\mathrm{m})\end{array}$ \\
\hline 1 & $1.7 \mathrm{E}-08$ & 0.053 \\
\hline 2 & $3.7 \mathrm{E}-08$ & 0.017 \\
\hline 3 & - & 0.041 \\
\hline 4 & $2.3 \mathrm{E}-08$ & 0.002 \\
\hline 5 & - & 0.008 \\
\hline 6 & $1.7 \mathrm{E}-08$ & 0.018 \\
\hline 7 & - & 0.002 \\
\hline 8 & - & 0.013 \\
\hline 9 & $3.2 \mathrm{E}-08$ & 0.010 \\
\hline 10 & - & 0.016 \\
\hline 11 & - & 0.050 \\
\hline 12 & $3.0 \mathrm{E}-08$ & 0.031 \\
\hline 13 & - & 0.021 \\
\hline 14 & $3.7 \mathrm{E}-08$ & 0.000 \\
\hline & & \\
\hline
\end{tabular}

TABLE 2. Differences in water level obtained during subsequent optimization procedures for low water period

\begin{tabular}{|c|c|c|}
\hline Junction number & $\begin{array}{c}\text { Difference in energy level between } \\
\text { parallel branches } \\
(\mathrm{m})\end{array}$ & $\begin{array}{c}\text { Difference between measured } \\
\text { and computed water level } \\
(\mathrm{m})\end{array}$ \\
\hline 1 & $5.1 \mathrm{E}-04$ & 0.018 \\
\hline 2 & $2.1 \mathrm{E}-04$ & 0.023 \\
\hline 3 & - & 0.058 \\
\hline 4 & $5.3 \mathrm{E}-04$ & 0.014 \\
\hline 5 & - & 0.019 \\
\hline 6 & $0.0 \mathrm{E}+00$ & 0.079 \\
\hline 7 & - & 0.075 \\
\hline 8 & - & 0.058 \\
\hline 9 & $6.7 \mathrm{E}-04$ & 0.058 \\
\hline 10 & - & 0.038 \\
\hline 11 & - & 0.030 \\
\hline 12 & $6.7 \mathrm{E}-04$ & 0.091 \\
\hline 13 & - & 0.072 \\
\hline 14 & $6.7 \mathrm{E}-04$ & 0.033 \\
\hline
\end{tabular}


slightly adjusted flow distribution gave satisfactory results (from 0.1 to $9 \mathrm{~cm}$, $5 \mathrm{~cm}$ on average) - Table 2 .

Validation stage was based on the independent set of discharge and water level observations during low flow period. This step was aimed at evaluating the accuracy of Manning's coefficients values identified in the optimization stage. Results indicate moderate differences in discharge distribution $\left(0.1 \mathrm{~m}^{3} / \mathrm{s}\right.$ on average) that was obligatory to obtain similar water levels at parallel branches and additionally against measured ones at junctions. Absolute differences between calculated and observed water levels at river junctions ranged between 1.6 and $15.6 \mathrm{~cm}(6.6 \mathrm{~cm}$ on average). Taking into account the absolute differences between modeled and measured water levels at parallel branches after flow optimization inaccuracies were negligible $\left(1.04 \cdot 10^{-5} \mathrm{~m}\right)$ - Table 3 .

There are few studies investigating similar research problems in the literature. It is mainly related to the lack of multi-channel anastomosing rivers that remain worldwide. Tabata and Hickin (2003) concluded their study, concerning hydraulic efficiency of anastomosing Columbia River (Canada), that there is a great need for additional studies investigating inter-channel hydraulic properties and flow conditions in anastomosing rivers. Similar to ours, but more simplified study was presented by Van et al. (2012), who developed a one-dimensional, steady-state HEC-RAS model for anastomosing section of Mekong river, considering two different hydrological conditions (high and low water stages). Since they declared no field measure-

TABLE 3. Differences in water level obtained during subsequent validation procedures for low water period

\begin{tabular}{|c|c|c|}
\hline Junction number & $\begin{array}{c}\text { Difference in energy level } \\
\text { between parallel branches } \\
(\mathrm{m})\end{array}$ & $\begin{array}{c}\text { Difference between measured and } \\
\text { computed water level } \\
(\mathrm{m})\end{array}$ \\
\hline 1 & $1.5 \mathrm{E}-05$ & 0.020 \\
\hline 2 & $7.8 \mathrm{E}-06$ & 0.017 \\
\hline 3 & - & 0.020 \\
\hline 4 & $1.1 \mathrm{E}-05$ & 0.026 \\
\hline 5 & - & 0.070 \\
\hline 6 & $0.0 \mathrm{E}+00$ & 0.083 \\
\hline 7 & - & 0.080 \\
\hline 8 & - & 0.063 \\
\hline 9 & $4.3 \mathrm{E}-05$ & 0.063 \\
\hline 10 & - & 0.157 \\
\hline 11 & - & 0.017 \\
\hline 12 & $2.6 \mathrm{E}-05$ & 0.130 \\
\hline 13 & - & 0.111 \\
\hline 14 & $4.3 \mathrm{E}-05$ & 0.072 \\
\hline
\end{tabular}


ments on the flow distribution and river cross-sections, they limited the research only to one bifurcation, finding more complex system too difficult to deal with using HEC-RAS model, supported exclusively by remotely sensed data. Nevertheless, their results indicated that for two different hydrological conditions, different Manning's coefficients are necessary, also obtaining higher coefficients for low water stages.

Yang et al. (2014) stated that selection of an appropriate value for Manning's coefficient significantly impacts the accuracy of a hydraulic model. However, they found it highly difficult as roughness depends on flow circumstances, stream's geomorphology and physical conditions. Even if it is done for a specific event it may not apply to another event due to its time- and site-dependency. In this study a detailed recognition of streams' geometry and flow distribution helped to reduce the inaccuracy of model simulations based on branch-assigned Manning's coefficients for different events.

\section{CONCLUSIONS}

Automatic procedure of Manning's coefficient identification constitutes a great modeling challenge, to date not present in the literature. The problem gets more complicated in anastomosing multi-channel systems, which are not frequently modeled. It determined developing a new MATLAB-based tool for one-dimensional steady-flow modeling (MFRM) supported by automatic roughness coefficient optimization algorithm. In this study two different conditions, in terms of hydrology and vegetation development, were investigated separately to highlight the impact of vegetation on flow distribution. For both cases field measurements were collected, necessary for model performance accuracy evaluation. Optimization and validation results clearly indicate that the MFRM is a sufficient tool for water flow modeling in anastomosing rivers. Therefore, it can be used for further analysis investigating the potential impact of protection measures on flow distribution and maintenance of anabranches in the NNP, which lately suffers from their extinction.

\section{Acknowledgments}

This research was financed by the National Science Centre, Poland under grant agreement 2015/19/N/ST10/01629.

\section{REFERENCES}

ARCEMENT G.J., SCHNEIDER V.R. 1989: Guide for Selecting Manning's Roughness Coefficients for Natural Channels and Flood Plains. USGS Water Supply Paper 2339. US Government Printing Office, Denver, CO.

BRUNNER G.W. 1995: HEC-RAS River Analysis System. Hydraulic Reference Manual. Version 1.0. Hydrologic Engineering Center Davis CA.

CISOWSKA I., HUTCHINS M.G. 2016: The effect of weirs on nutrient concentrations. Sci. Total Environ. 542, 997-1003.

HORRITT M.S., BATES P.D. 2002: Evaluation of 1D and 2D numerical models for predicting river flood inundation. $J$. $\mathrm{Hy}$ drol. 268, 1-4.

KICZKO A., ROMANOWICZ R.J., OSUCH M. 2011: Impact of water management policy on flow conditions in wetland areas. Phys. Chem. Earth 36, 13, 638-645. 
LEWIN J. 2010: Medieval environmental impacts and feedbacks: The lowland floodplains of England and Wales. Geoarchaeology 25, 267-311. doi 10.1002/ Gea.20308.

MARCINKOWSKI P., GRABOWSKI R.C., OKRUSZKO T. 2017: Controls on anastomosis in lowland river systems: towards process-based solutions to habitat conservation. Sci. Total Environ. 609, 1544-1555.

MASHRIQUI H.S., HALGREN J.S., REED S.M. 2014: 1D River Hydraulic Model for Operational Flood Forecasting in the Tidal Potomac: Evaluation for Freshwater, Tidal, and Wind-Driven Events. J. Hydraulic Eng. 140, 5.

NANSON G.C., CROKE J.C. 1992: A genetic classification of floodplains. Geomorph. 4, 459-486.

NANSON G.C., KNIGHTON A.D. 1996: Anabranching rivers: their cause. character and classification. Earth Surf. Proc. Landforms 21, 217-239.

PAPPENBERGER F., BEVEN K.J., HORRITT M.S., BLAZKOVA S. 2005: Uncertainty in the calibration of effective roughness parameters in HEC-RAS using inundation and downstream level observations. J. Hydrol. 302, 46-69.

PRÓCHNICKI P. 2005: The expansion of common reed (Phragmites australis (Cav.) Trin. ex Steud.) in the anastomosing river valley after cessation of agriculture use (Narew River valley, NE Poland). Pol. J. Ecol. 53, 353-364.

RIIS T., BIGGS B.J. 2003: Hydrologic and hydraulic control of macrophyte establishment and performance in streams. Limnol. Oceanogr. 48 (4), 1488-1497.

ROMANOWICZ R., KICZKO A., NAPIÓRKOWSKI J. 2009: Stochastic Transfer Function Simulator of a 1-D. Publs. Inst. Geophys. Pol. Acad. Sc. E-10.

ROMANOWICZ R., KICZKO A., NAPIÓRKOWSKI J. 2010: Stochastic transfer function model applied to combined reservoir management and flow routing. Hydrol. Sci. J., 55, 1.
TABATA K.K., HICKIN E.J. 2003: Intrachannel hydraulic geometry and hydraulic efficiency of the anastomosing Columbia river, southeastern British Columbia, Canada. Earth Surf. Proc. Landforms 28, 837-852. doi:10.1002/esp.497.

VAN T.P.D., CARLING P.A., ATKINSON P.M. 2012: Modelling the bulk flow of a bedrock-constrained, multi-channel reach of the Mekong River, Siphandore, southern Laos. Eartl Surf. Proc. Land 37, 533-545.

WALTER R.C., MERRITTS D.J. 2008: Natural streams and the legacy of waterpowered mills. Science 319, 299-304. doi:10.1126/science.1151716.

YANG T.H., WANG Y.C., TSUNG S.C., GUO W.D. 2014: Applying micro-genetic algorithm in the one-dimensional unsteady hydraulic model for parameter optimization. J. Hydroinfor. 16 (4), 772-783.

Streszczenie: Modelowanie przeptywu wody $w$ wielokorytowym systemie rzecznym $w$ Narwiańskim Parku Narodowym. Rzeki anastomozujące są bardzo rzadkim przykładem rzek wielokorytowych, które były często spotykane przed intensywnym zagospodarowaniem dolin rzecznych na rzecz rolnictwa i przemysłu. Obecnie na świecie zaledwie kilka rzek utrzymało wielokorytowy charakter, a ostatnim przykładem w Polsce jest fragment rzeki Narew w Narwiańskim Parku Narodowym. Mimo że modelowanie hydrauliczne przy wykorzystaniu modeli jednowymiarowych jest często używane do opisu przepływu wód, dla rzek wielokorytowych problem ten jest dużo bardziej złożony. Dla tego typu rzek oczekiwane jest silne sprzężenie zwrotne między intensywnością wzrostu roślin (wyrażoną poprzez współczynnik Manninga) a rozdziałem przepływu między ramionami rzeki. Proces identyfikacji współczynników szorstkości w rozgałęziających i ponownie łączących się odnogach rzeki jest trudne i pracochłonne. Dla efektywnego modelowania przepływu wód rzek wielokorytowych opracowany został osobny model wyposażony w procedurę automatycznej identyfikacji parametrów szorstkości. Proces optymalizacji i weryfikacji modelu na podstawie pomiarów terenowych rzędnych zwierciadła wody oraz natężenia przepływu wykazał jego poprawność i dużą dokładność w symulowaniu przepływu wód w rzekach wielokorytowych. 
MS received July 2017

Authors' address:

Paweł Marcinkowski, Adam Kiczko,

Tomasz Okruszko

Katedra Inżynierii Wodnej

Wydział Budownictwa i Inżynierii Środowiska

SGGW

ul. Nowoursynowska 159, 02-776 Warszawa

Poland

e-mail: p.marcinkowski@levis.sggw.pl 